\author{
N.A. Yesmagambet, A.S. Omarov \\ Ye.A. Buketov Karaganda State University, Kazakhstan \\ (E-mail: omarovanuar91@mail.ru)
}

\title{
Research and development of deployable solar tracking system in SolidWorks for multiple tasks
}

\begin{abstract}
Nowadays, we have a problem of uninterrupted automatic operation of unmanned ground vehicles (UGV). The appliance of alternative types of energy, in particular solar, as a system of main or additional power source in automatic mode, can be carried out in the body of a ground robot. Within the limited space in the trunk, it is necessary to place the solar panels and actuators densely as possible, and also effectively locate the plane of the unfolded panels in relation to the sunrays. For these reasons, a deployable solar tracking system was developed and analyzed. There were made calculations of the number of necessary solar energy, cells and panels for the effective charging of the UGV in automatic mode, construction of a 3D model of the device in SolidWorks, selection of the design of the deploying mechanism based on the motion analysis and simulation of the model, identification of location of the charging system within the existing UGV. The further stages of research are determined.
\end{abstract}

Keywords: solar, tracking, SolidWorks, deployable, automative system, ugv, portable, alternative energy, 3D modelling.

Continuous automatic functioning of the UGV can not be performed for a long time without timely charging of the batteries. One of the solutions to the problem is using of solar energy, which makes it possible to receive the necessary energy in an automatic mode, no tight binding to a certain place of charging, the amount of energy received is limited only by the capacity of the battery and the state of the environment. Among the imperfections, it can be noted an increase of the UGV's weight, the dependence on weather conditions and lower rate of charging of the storage batteries. Sufficient charging efficiency with the solar panels in a given limited space of the UGV design can be compensated by the introduction of deploying system. Therefore, the coverage area of the unfolded solar panels is increasing several times in comparison with the occupied area in the trunk.

UGV automatically executes deploying of the solar system at a definite threshold of battery charge, at sufficient solar illumination and in a safe state of the environment. After a full disclosure, the system begins tracking of the best position of the solar panels, in which the sunrays fall at right angles to the surface. Tracking panels in two axes will increase the efficiency of the charging by 81.68 percents [1]. In the case of battery is fully charged or unfavorable conditions are occurred, the system folds the panels into the UGV's body.

According to the analyzed characteristics of different types of mono and polycrystalline solar cells, one of the optimal solutions is to use Maxeon C60 with nominal parameters, shown in Table 1, and I-V curve presented in Figure 1.

Table 1

Electrical characteristics of Maxeon $\mathrm{C} 60$ solar cell at $25^{\circ} \mathrm{C}$

\begin{tabular}{|c|c|c|c|c|c|}
\hline Pinpp(Wp) & Eff.(\%) & $\operatorname{Vmpp}(\mathrm{V})$ & $\operatorname{Impp}(\mathrm{A})$ & $\operatorname{Voc}(\mathrm{V})$ & $\operatorname{Isc}(\mathrm{A})$ \\
\hline 3.38 & 22.1 & 0.577 & 5.87 & 0.684 & 6.26 \\
\hline
\end{tabular}




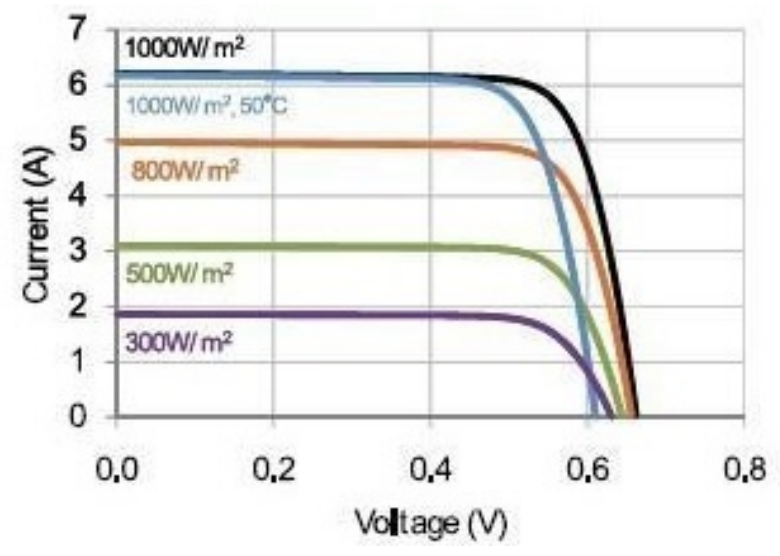

Figure 1. Maxeon C60 I-V curve

The future system must satisfy the following conditions:

- Dimensions compactness;

- Maximum simplicity of the design;

- Resistance to changes of weather conditions;

- The most effective placement of Maxeon C60 solar cells in a box measuring 420x250x800 mm.

The most suitable technology is a Smart Flower [2] for the first three criteria. To satisfy the fourth criteria, a slightly different design of the panels must be chosen. The most effective shape of the panels for the arrangement of Maxeon C60 solar cells is a square or rectangle, with the sides that are multiple to $125 \mathrm{x} 125 \mathrm{~mm}$ cell dimensions. The average output voltage of one cell is $0.5 \mathrm{~V}$, in cloudy days $0.25 \mathrm{~V}$. For a stable power supplying of a $12 \mathrm{~V}$ system, even in overcast weather, it will be required about 36-40 solar cells. The most optimal solution is the deploying mechanism [3] with four rectangular panels with dimensions of 260x640 mm, on which 10 solar cells can be arranged. With a relatively simple design and actuators, the coverage area of the solar panels increases four times. Of course, the origami method [4] can execute magnifications of more than 20 times, but to deploy such small area, it is necessary to use very thin panels that, even in conditions of slight windiness, have weak stability.

SolidWorks software has been used to create and calculate the motion of the deployable tracking solar system model (Fig. 2-5).

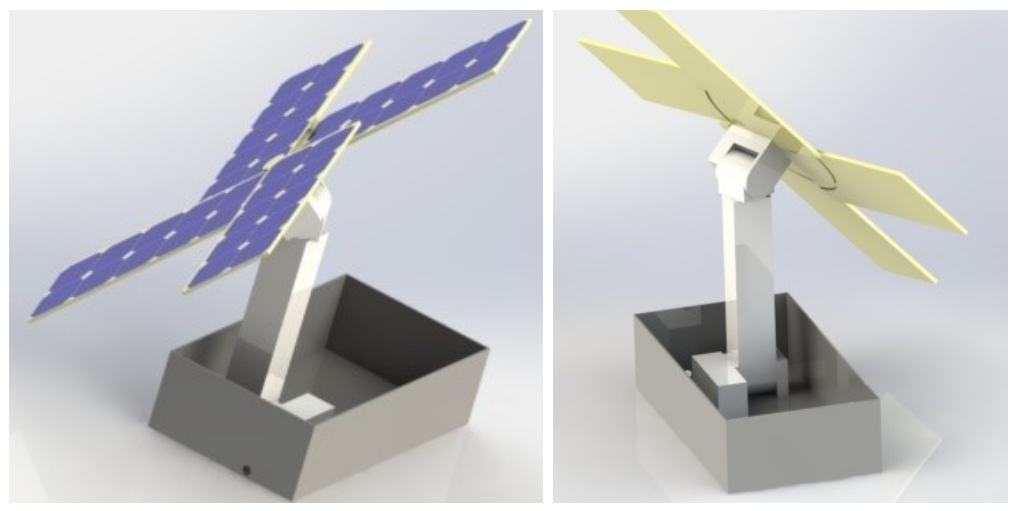

Figure 2. Fully deployed system

To store the system in the body of the UGV, there were made several structural changes, because the occupied area has the highest priority. Compactness in length can be obtained by reducing the support stand, but in this case we have to raise it in a pair with the movement of tracker axes. This compensation is necessary because of the collision when lifting only one support stand. Such change decreases the length of the box 2 times. 


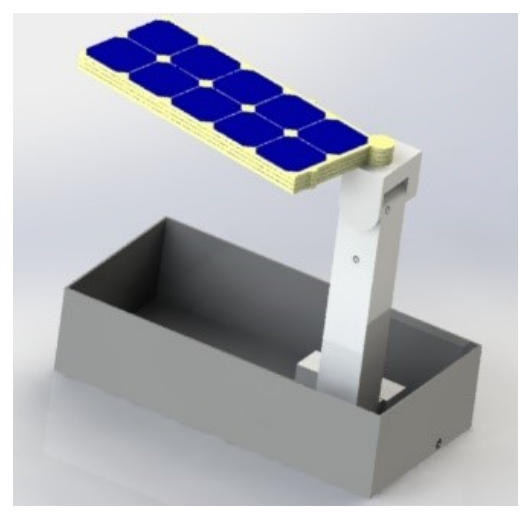

Figure 3. Support stand in unfolded position

The center of the clutch with the shaft located in the corner of the panel, so the folded panels should be placed at angle of 12.72 degrees to effectively use the space in the box (Fig.4).

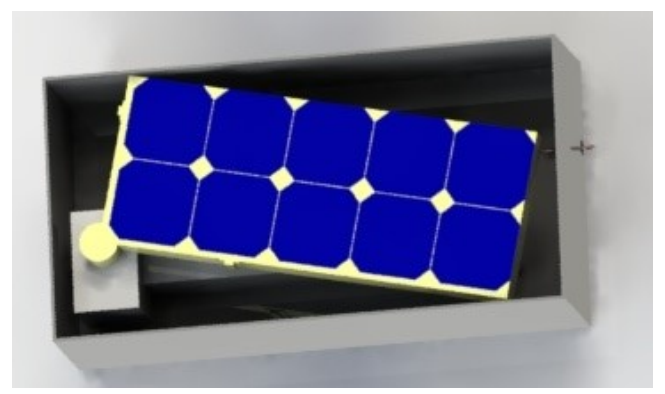

Figure 4. Solar system in folded position

As a result, we receive a box with dimensions of 410x220x750 mm, which is quite satisfactory for the dimensions of the available UGV's trunk.

For deploying system, it has been used compact DC motors with high RPM in pair with gearboxes based on cylindrical and bevel gears. The wiring of the motors passes through the centers of the shafts of each execution block. More detailed placement of motors, wiring and actuators is shown in Figure 5.
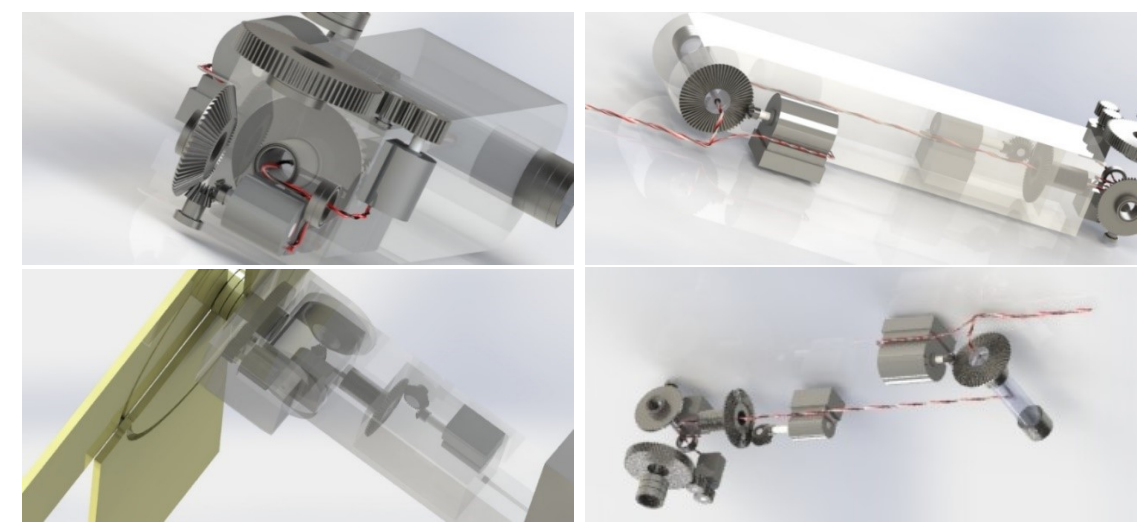

Figure 5. Location of motors, wiring and actuators

In result, developed solar system [5] has a number of advantages: portable, compact, energy efficient, ecological clean, autonomous. A system of this kind can easily be applied into various areas of obtaining an energy. In the future, it is planned to implement the system on an existing UGV. 


\title{
References
}

1 Dhanabal R. Сравнение эффективности систем солнечного слежения со статической панелью одноосной следящей системы и двухосевой системой слежения с фиксированным креплением / R.Dhanabal, V.Bharathi, R.Ranjitha, A.Ponni, S.Deepthi, P.Mageshkannan // Международный журнал инженерии и технологий (IJET). - 2013. — Т. 5. — № 2. - С. 1925-1933.

2 Swatek А. Солнечный модуль / A.Swatek, C.Schondorfer, E.Stoger // Патент №US8664511B2, Smart Flower Energy Technology Gmbh, 2014.

3 [Электронный ресурс]. - Режим доступа: https://youtu.be/0G_rI8Aau7M. Раскрываемый механизм, разработанный доктором инженерии Nguyen Duc Thang.

4 Fei L.J. Теория оригами и ее применение: литературный обзор / L.J.Fei, D.Sujan // Международный журнал гуманитарных и социальных наук (IJHSS). - 2013. - T. 7. — № 1. - С. 229-233.

5 [Электронный ресурс]. - Режим доступа: https://youtu.be/XBU90pG5Rx8. Развертываемая солнечная следящая система в SolidWorks.

\section{Н.А. Есмағамбет, А.С. Омаров \\ Әртүрлі тапсырмаларды орындау үшін SolidWorks-те күн шуақтарымен түсіндірілетін бақылау жүйесін зерттеу және дамыту}

\begin{abstract}
Қазіргі уақытта адамсыз жер үсті көлігінің (АЖҮК) үзіліссіз автоматты түрде жұмыс істеу мәселесі көтерілуде. Энергияның балама түрлерің пайдалануы, атап айтқанда, күн, негізгі немесе қосымша нәр беруші жүйелер ретінде автоматты түрде жердегі роботтың корпусында жүзеге асыруға болады. Шектеулі кеңістіктен корпуста барынша ықшамды күн тақтасын және атқарушы механизмдерді орналастыру қажет, тағы да күн сәулелеріне қатысты ашық панельдердің жазықтығын тиімді орналастыру керек. Осы мақсатта күн шуақтарымен түсіндірілетін бақылау жүйесі талданды және әзірленді. АЖҮК автоматты түрде тиімді зарядтау үшін күн энергиясын, жасушалар, тақталардың қажетті саны есептелген. Түсіндірілетін механизмдердің құрылымдарына таңдау жасалды. Аппараттың 3Д-моделі құрылды. Қажетті конструкциялардың қозғалысты талдау негізі және модельдің симуляциясына есептеу жүргізілді. Шектеулі кеңістіктең қазіргі бар АЖКК зарядтау жүйесін орналасқан жерін білдіреді. Бұдан әрі зерттеудің кезеңдері анықталды.
\end{abstract}

Kiлm сөздер: күндік, бақылау, SolidWorks, автоматты жүйесі, АЖКК, портативті, баламалы энергия, ЗД-модельдеу.

\author{
Н.А. Есмагамбет, А.С. Омаров
}

\section{Исследование и разработка развертываемой солнечной следящей системы в SolidWorks для выполнения различных задач}

\begin{abstract}
В настоящее время проблема бесперебойной автоматической работы беспилотных наземных аппаратов (БПНА) особенно остра. Использование альтернативных видов энергии, в частности солнечной, как системы основного или дополнительного источника питания в автоматическом режиме можно осуществить в корпусе наземного робота. В рамках ограниченного пространства в корпусе необходимо максимально компактно разместить солнечные панели и исполнительные механизмы, а также плоскость раскрытых панелей относительно солнечных лучей. Для этого разработана и проанализирована развертываемая солнечная следящая система. Рассчитано количество необходимой солнечной энергии, ячеек, панелей для эффективного заряда БПНА в автоматическом режиме. Осуществлен выбор конструкции развертываемого механизма. Построена ЗД-модель аппарата. На основе анализа движения и симуляции модели произведен расчет необходимой конструкции. Обозначено расположение системы дозарядки в рамках существующего БПНА. Определены дальнейшие этапы исследования.
\end{abstract}

Ключевые слова: солнечная, следящая, SolidWorks, развертываемая, автоматическая система, БПНА, портативная, альтернативная энергия, ЗД-моделирование. 


\section{References}

1 Dhanabal, R., Bharathi, V., Ranjitha, R., Ponni, A., Deepthi, S., \& Mageshkannan, P. (2013). Sravnenie effektivnosti sistem solnechnoho slezheniia so staticheskoi paneliu odnoosnoi slediashchei sistemoy i dvukhosevoi sistemoi slezheniia s fiksirovannym krepleniem [Comparison of Efficiencies of Solar Tracker systems with static panel SingleAxis Tracking System and Dual-Axis Tracking System with Fixed Mount]. Mezhdunarodnyi zhurnal inzhenerii i tekhnologii (IJET) - International Journal of Engineering and Technology (IJET), 5, 2, 1925-1933 [in Russian].

2 Swatek, A., Schondorfer, C., \& Stoger, E. (2014). Solnechnyi modul [Solar module]. Patent № US8664511B2, Smart Flower Energy Technology Gmbh.

3 youtube.com. Retrieved from https://youtu.be/0G_rI8Aau7M. Raskryvaemyi mekhanizm, razrabotannyi doktorom inzhenerii Nguyen Duc Thang [Deploying mechanism created by Doctor of Engineering Nguyen Duc Thang].

4 Fei, L.J., \& Sujan, D. (2013). Teoriia orihami i ee primenenie: literaturnyi obzor [Origami Theory and its Applications: A Literature Review]. Mezhdunarodnyi zhurnal humanitarnykh i sotsialnykh nauk (IJHSS) - International Journal of Humanities and Social Sciences (IJHSS), 7, 1, 229-233 [in Russian].

5 youtube.com. Retrieved from https://youtu.be/XBU90pG5Rx8. Razvertyvaemaia solnechnaia slediashchaia sistema v SolidWorks [Deployable solar tracking system in SolidWorks]. 